\title{
Need for sustainability policy - a case study of the Natural Forest Conservation Program (NFCP) in the western region of Tianshan Mountain, China
}

\author{
by Qiang Wang ${ }^{1}$, Xiao Ruan², Cun-De Pan ${ }^{3}$, Ning-Yi Xu ${ }^{4}, X_{i a} L_{u}{ }^{5}$ and Min-Ming Huang ${ }^{6}$
}

\begin{abstract}
A case study of the Natural Forest Conservation Program (NFCP) in the western region of Tianshan Mountain was undertaken between 2001 and 2003. Data on the geographic, climatic, ecological, and social economy background of the study area were collected. The impact of the NFCP on the forest, soil, water, and biodiversity in the study area were analyzed and evaluated. The results show that a complete logging ban in the study area cannot replace sustainable forest management; a more flexible policy should be adopted to resolve technical, social and economic problems associated with the complete and suddenly implemented logging ban. In order to strengthen the long-term sustainability of the NFCP, public awareness and funding support China should be increased.
\end{abstract}

Key words: sustainability, Natural Forest Conservation Program, NFCP, forest management, Tianshan Mountain

\section{RÉSUMÉ}

Une étude de cas tirée du Programme de conservation des forêts naturelles (PCFN) de la région occidentale du Mont Tianshan a été entreprise entre 2001 et 2003. Des données sur la géographie, le climat, l'écologie et l'économie sociale de la région sous étude ont été recueillies. L'impact de du PCFN pour cette étude sur la forêt, le sol, l'eau et la biodiversité a été analysé et évalué. Les résultats démontrent qu'une interdiction complète de l'exploitation forestière dans cette région sous étude ne peut remplacer l'aménagement durable des forêts ; une politique plus souple devrait être adoptée pour résoudre les problèmes techniques, sociaux et économiques associés à l'interdiction de l'exploitation forestière complète et abruptement mise en place. De façon à renforcer la durabilité à long terme du PCFN, la sensibilisation du public et le support financier en Chine devraient être augmentés.

Mots clés : durabilité, Programme de conservation des forêts naturelles, PCFN, aménagement forestier, Mont Tianshan

\section{Introduction}

Despite thousands of years of human land use, large areas of old-growth forest still existed in China at the beginning of the 20th century (Shaw 1914). Before the 1950s, most of China's forests were naturally regenerated. Since then, demand for timber has resulted in extensive cutting of forests, and timber harvests increased from 20 million $\mathrm{m}^{3}$ /year in the 1950s to 63 million $\mathrm{m}^{3}$ /year in the 1990s (Ministry of Forestry 1997). Natural forests declined to $30 \%$ of the total forest area in China and unit-area stocking of natural forests decreased by 32\% (Zhang et al. 1999). The sharp decline in the quantity and quality of natural forests resulted in loss and fragmentation of natural habitats. At least 200 plant species have become extinct in China since the 1950s, and more than 61\% of wildlife species have suffered severe habitat losses. Valuable and rare species, such as ginseng (Panax ginseng), are threatened with extinction (Li 1993). Changes in forest composition have also caused severe ecological and environmental disasters. Insect infestations have damaged more than 9.3 million ha of forests per year, causing over 10 million $\mathrm{m}^{3}$ of timber loss. Flash flooding, in part the result of loss of natural vegetative cover, caused a total loss of 166.6 billion yuan renminbi (RMB, US $\$ 20$ billion) in the summer of 1998 alone (Qu 1999).

In 1998, flash flooding took place in almost all major river basins. The central government of China attributed the flooding to deforestation in the upper reaches of major river systems and ordered logging restrictions in many state-owned forested areas. The new initiative - the Natural Forest Conservation Program (NFCP) - began in the fall of 1998

\footnotetext{
${ }_{1}^{1}$ Qiang Wang, Vice-professor, Ningbo Institute of Technology, Zhejiang University, Ningbo, 315100, P.R. China. E-mail: wangqiangsky@263.net ${ }^{2}$ Xiao Ruan, Vice-professor, Ningbo Institute of Technology, Zhejiang University, Ningbo, 315100, P.R. China. E-mail: ruanxiao8888@163.com ${ }^{3}$ Cun-De Pan, Professor, College of Forest, Xinjiang Agricultural University, Urumqi, 830052, P. R. China. E-mail: pancunde@163.com (corresponding author)

${ }^{4}$ Ning-Yi Xu, Ningbo Institute of Technology, Zhejiang University, Ningbo, 315100, P.R. China. E-mail: xuny121@21cn.com

${ }^{5}$ Xia Luo, Ningbo Institute of Technology, Zhejiang University, Ningbo, 315100, P.R. China. E-mail: luoxialkz2004@163.com

${ }^{6}$ Min-Ming Huang, Ningbo Institute of Technology, Zhejiang University, Ningbo, 315100, P.R. China. E-mail: hmmm1102@163.com
} 


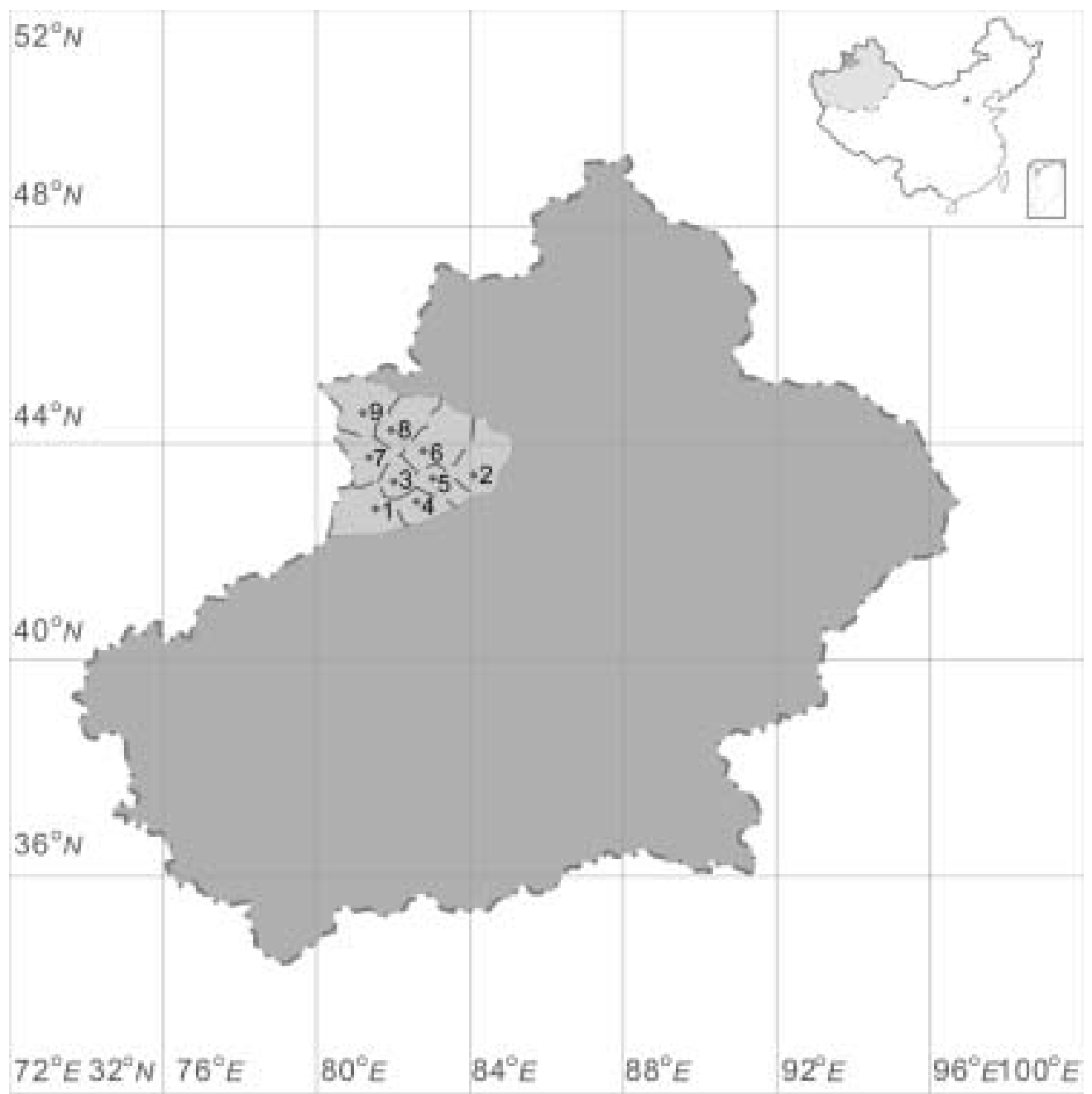

Fig. 1. Location of the nine forest centers in the west region of Tianshan Mountain (1: Zhaosu Forest Center; 2 : Xinyuan Forest Center; 3: Chabucha'er Forest Center; 4: Teke'se Forest Center; 5: Gongliu Forest Center; 6: Nileke Forest Center; 7: Huocheng Forest Center; 8: Yining Forest Center; 9: Mengmala Forest Center]

in several major forested areas. The NFCP was designed to run from 1998 to 2010. State-owned forests in the upper stream areas of the Yangze and Yellow Rivers are grouped into ecological service forests across 13 provinces in central and southwest china. The goals of the NFCP are to restore natural forests in ecologically sensitive areas, plant trees for soil and water protection, develop high-productivity forest plantations, protect existing natural forests from excessive logging and maintain a multiple-use strategy in natural forests (Zhao and Shao 2002).

The NFCP is being managed by a new government agency called the Center for Natural Forest Conservation and Management (CNFCM), which is under the State Forestry Administration. The CNFCM is applying a mixture of public policy instruments to achieve the objectives of the NFCP, including technical training and education, land management planning, mandatory conversion of marginal farm lands to forest lands, resettlement and restraining of forest dwellers, share in private ownership and expanded research (Zhang et al. 2000).
In order to monitor the implementation of the NFCP, a case study in the western region of Tianshan Mountain in Xinjiang Province was undertaken from 2001 to 2003. The resultant report documented the geographic, climatic, ecological and social economy background of the region, described the survey methodology and analyzed the impact on forest, soil, water, and biodiversity of the NFCP in the study area. It also discussed the technical, social and economic problems associated with implementation of the NFCP at the regional level and gave some suggestions for the sustainability of policy.

\section{Geographic, Climatic, Ecological and Social Economy Background of the Study Area}

\section{Geographic}

The western region of Tianshan Mountain is located in what was delineated as the Yili district, a part of the Yili Kazakh Autonomous Prefecture of Xinjiang, People's Republic of China. The study area is in a mountain and valley area in the 
upper reaches of the Yili River. The Yili River is among the richest inland water sources in China. The watershed of the river is about $61000 \mathrm{~km}^{2}$ in area. The study area is 56339 $\mathrm{km}^{2}$, about $350 \mathrm{~km}$ long from east to west and $280 \mathrm{~km}$ wide from north to south, of which cultivable land occupies $9.92 \%$ (of which $70.92 \%$ is actually cultivated), 6.54\% is forest land, $64.35 \%$ is grassland (of which $98.03 \%$ is natural grassland) and unutilized land or land of other use is $19.19 \%$ (Fig. 1). Population density averages 37 persons per $\mathrm{km}^{2}$. The overall topography of the area rises from west to east, with the lowest elevation being at the base of the Yili Valley (500 to $900 \mathrm{~m}$ ) and with the highest elevations being those of the Zhaosu basin and the Tekese valley base, which range from 900 to $2000 \mathrm{~m}$. In terms of land composition, the region is composed of $65.69 \%$ mountains, $10.50 \%$ hills, $20.76 \%$ plains, $0.60 \%$ deserts, $1.38 \%$ marsh, $0.71 \%$ Gobi desert, and $0.90 \%$ water.

\section{Climate}

The Yili Basin has a temperate climate, which is suitable for the growth of plants and animals. Besides having plentiful rainfall, the basin is warm and dry in the summer and temperate and wet in the winter, with no bitter cold. The annual mean temperature is $0.7^{\circ} \mathrm{C}$ to $9.2^{\circ} \mathrm{C}$. The warmest month is July, with a mean temperature of $14.4^{\circ} \mathrm{C}$ to $23.4^{\circ} \mathrm{C}$, while the coldest month is January with a daily mean temperature of $12.2^{\circ} \mathrm{C}$ to $-6.8^{\circ} \mathrm{C}$. The frost-free period in the western part of the basin is 160 to 180 days per year, while it is 140 to 160 days per year in the eastern part of the basin. Precipitation from west to east ranges from $200 \mathrm{~mm}$ to $850 \mathrm{~mm}$ annually. Snow is plentiful in winter on the mountains, with annual snowfall days ranging from 110 to 120 and the accumulated depth of snowfall ranging from 40 to $50 \mathrm{~cm}$. The area is considered to be one of the regions in the province with the greatest amount of snow. Because of the difference of landforms within the watershed, precipitation varies from place to place, with more towards the mountains and more in the east than west.

\section{Vegetation}

There are five main types of vegetation in the study area: desert, steppe, meadow, forest, and azonal vegetation. The region has been listed (Chen 1993) as one of the five key regions in the country with nationwide significance in terms of terrestrial biodiversity. Characteristics of the main vegetation types found in the area are summarized in Table 1. There are about 2500 species of higher plant in the study area. Besides many arctic alpine components on the alpine belt, there are some relic species such as wild apple (Malus sieversii (LDB) Roem.), wild walnut (Juglans regia L.), wild apricot (Armeniaca vulgaris Iam.), Tianshan Acer (Acer semenovii Rgi.), and Tianshan Euonyma (Euonymus semenovii Rgi. et Herd.). In addition, there are about 30 wild animal species in the Yili River Basin, nearly 100 bird species, more than 500 insect species, and some still-unidentified species with the faunal components belonging to the Paleo-Arctic type. Among the faunal species in the area, there are eleven species that belong to the national list of Endangered (EN) and 56 species belonging to the list of Vulnerable (VU).

Of particular interest for this case study are the three forest types found in the area: mountain coniferous, mountain broad-leafed, and valley secondary. The majority of forest in the Yili River Basin is of the mountain coniferous type and made up mainly of Picea schrenkiana Fisch. et Mey. Because of the wet climate, however, forest on the mountains is not completely coniferous, with broad-leafed forest belts near the bottom and $P$. schrenkiana making up the coniferous belt at altitudes above $1600 \mathrm{~m}$. P. schrenkiana, in addition to being an important timber resource, has important soil and water conservation functions and makes up $98.6 \%$ of the total stand volume in the region. It is mainly distributed at elevations between 1600 and $2800 \mathrm{~m}$. At elevations between 1200 and $1600 \mathrm{~m}$, the spruce is often mixed with aspen (Populus tremula L.) and birch (Betula tianschanica Rupr.). The highest productivity P. schrenkiana forest — average stand age 150 years - is found in the forest area of Gongliu, where a total standing stock of 600 to $800 \mathrm{~m}^{3}$ per ha is often found.

Broadleaf forest, distributed at elevations between $800 \mathrm{~m}$ and $1800 \mathrm{~m}$, makes up about $0.9 \%$ of forest area and consists mainly of birch (Betula tianschanica Rupr.), aspen (Populus tremula L.), and wild fruit tree forest. The last includes wild apple (Malus sieversii (LDB) Roem.), wild walnut (Juglans regia L.), and wild apricot (Armeniaca vulgaris Iam.).

Valley secondary forest is mainly distributed along the banks of the Teke'se, Gongnai'se, Kash, and Yili Rivers, covering 23667 ha. Trees make up about 16\% of this forest, with a standing volume of about $214000 \mathrm{~m}^{3}$. Main tree species include Populus talassica, Betula tianschanica, Fraxinus bungeana, and Salix spp. Shrub species are Hippophae, Berberis, Lonicera, Rosa, and Caragana. Populus talassica is characteristic of the Yili Valley and is also a main component of the local community. In China, Bunge ash (Fraxinus sogdiana Bge.) is found only in this area and is considered a precious genetic resource.

\section{Soil type}

The soil in the study area is divided into 13 soil groups, 41 subgroups, 39 soil genera, 86 soil species, and 104 soil varieties. Types of cultivated soil include sierozem, castanozem, and chernozem. The uncultivated land on valley flatland includes meadow soil, chernozem, castanozem, and marshy soil types. Hill and mountain soils mainly include alpine frozen soil, alpine meadow soil, and chernozem. The main parent materials of soils in forest areas are residual deposit and diluvium slope wash. Secondary to these are diluviumalluvial deposit and loess-like sediment of different origins. Soil distribution exhibits horizontal zonality within valleys, with a typical distribution being sierozem in the west transitioning to castanozem, and then, in some cases, chernozem, and eastwards with increase in rainfall. Vertical zonality of mountain soil distribution is relatively obvious around each of the region's valleys and includes, moving from bottom to top, castanozem, mountain chernozem, grey brown forest soil, subalpine meadow soil, and alpine meadow soil.

\section{Timber harvest in natural forest in the study area}

The historical records show that logging in the mountain forests of the Yili River Basin has not stopped for the nearly 200 years recorded. While cutting prior to 1949 was partial and unorganized, after 1949 extensive exploitation of natural forest resources was carried out successively across the whole of the Yili River Basin. From 1950 to 1955, logging was carried out only at the Zhaosu Forest Center. From 1955 to 1961, seven other forest centers for logging were established, includ- 
Table 1. Characteristics of the main vegetation types in the study area

\begin{tabular}{|c|c|}
\hline Vegetation Type & Characteristics \\
\hline \multirow[t]{2}{*}{ Desert } & Kashgar Artemisia community in foothills at about $950 \mathrm{~m}$, with coverage of $25 \%$ to $35 \%$ \\
\hline & Nanophyton desert community in higher elevation foothills, with coverage of $10 \%$ to $30 \%$ \\
\hline \multirow[t]{4}{*}{ Steppe } & Major vegetation perennial species of family Gramineae \\
\hline & Desert steppe includes Stipa caucasica community, Stipa cappillata community, and Festuca community \\
\hline & True steppe includes Stipa cappillata and Festuca community \\
\hline & Meadow steppe includes high perennial mesophytic grasses and forbs \\
\hline \multirow[t]{2}{*}{ Meadow } & $\begin{array}{l}\text { Subalpine meadow usually from } 1800 \text { to } 2800 \mathrm{~m} \text {, with tall and dense vegetation, including the tall forbs Aconitum, } \\
\text { Cisium, and Consolida }\end{array}$ \\
\hline & $\begin{array}{l}\text { Alpine meadow belt at altitudes of over } 2800 \mathrm{~m} \text {; Relatively short vegetation, including Carex, Polygonum viviparum, } \\
\text { Gentiana algida, and Geranium. }\end{array}$ \\
\hline \multirow[t]{4}{*}{ Forest } & Three types: mountain coniferous, mountain broad-leafed, and valley secondary forest \\
\hline & Mountain coniferous includes Picea schrenkiana Fisch. et Mey. \\
\hline & $\begin{array}{l}\text { Mountain deciduous only } 0.9 \% \text { of forest area; Includes Populus tremula L., Betula tianschanica Rupr., and wild fruit } \\
\text { tree forest }\end{array}$ \\
\hline & $\begin{array}{l}\text { Valley secondary forest:16\% trees with the rest shrub, such as Hippophae, Berberis, Lonicera, Rosa, and Caragana. } \\
\text { Populus talassica }\end{array}$ \\
\hline \multirow[t]{3}{*}{ Azonal } & $\begin{array}{l}\text { Mainly distributed on lower land includes mesophytic and draught mesophytic grasses, as well as some forbs; sub- } \\
\text { divided as meadow vegetation and marsh vegetation }\end{array}$ \\
\hline & $\begin{array}{l}\text { Meadow vegetation at riversides and higher flood land; aside from forbs and grasses, flood land includes secondary } \\
\text { forest with Populus, Salix, Ulmus, Acer semenovii Rgi., and Fraxinus sogdiana Bge. }\end{array}$ \\
\hline & $\begin{array}{l}\text { Marsh vegetation mainly at the lower parts of boundary-less flood land; Composed of mixture of plants, such as } \\
\text { Phragmites communis Trin., Dolichandron caudafelina Benth. et Hook. }\end{array}$ \\
\hline
\end{tabular}

ing Xinyuan (1956), Chabucha'er (1956), Teke'se (1957), Gongliu (1959), Nileke (1960), Huocheng (1960), and Yining (1961) Forest Centers. The number of forest centers was brought to its current total of nine with the establishment of the Mengmala Forest Center in 1971. Production of commercial timber from 1950 to 2000 was 5.79 million $\mathrm{m}^{3}$, with total consumption of forest resources being 8.27 million $\mathrm{m}^{3}$. In the process of producing commercial timber, 21694.3 ha have been logged, of which 9540.4 ha were clearcut and 12 153.87 ha were harvested under a selection system. These areas, respectively, account for $11 \%$ and $4.9 \%$ of the forested area (defined as having a canopy density of greater than or equal to 0.35 ).

\section{Characteristics of the population and workforce}

After 200 years of evolution, the composition of ethnic groups in the study area has changed from that of a single nomadic Kazakh ethnicity to the over 40 ethnicities represented today. Table 2 shows the ethnic composition of the region at different times over the last 50 years as well as the total population, which now consists of over two million persons.

In terms of economic sectors, the majority of the labour force $(69.91 \%)$ is engaged in the primary sector, including agriculture, forestry, animal husbandry, and fisheries (Table 3 ). While the development of the local economy has been slow, it has weak ability to create employment. Since 1990, the registered urban unemployed as a proportion of total workforce has remained stable at over 4\% (Table 4). This shows that the unemployment problem in the towns of the area is rather serious.

\section{Development of the tourism industry}

Although tourism resources in the Yili Watershed are very rich, the industry is not very developed in the region. Currently, annual income categorized as tourism income is less than 20 million yuan renminbi (RMB, US\$ 2.4 million); and the industry is considered to have only just started. Foreign tourists come mainly from the Commonwealth of Independent States (the former Soviet Union), which accounts for $95 \%$ of foreign tourists. The main aim of tourists from the former Soviet Union is not sightseeing, but rather buying goods, mostly wholesale for resale in their own countries. This can be seen from the role of "product income" in overall tourism income. Few tourists come to Yili from other parts of Xinjiang due to the underdeveloped economy and low living standards in the province. Even fewer come from other parts of China, because of the long distances involved. Thus, the role of tourism in the watershed's economy is still very low; and its ability to absorb surplus labour is weak. From the types and number of tourism resources in the region, however, it can be seen that the potential for the development of the industry is great, so that it could become one of the region's main industries in the future.

\section{Survey Methodology}

Fieldwork was conducted from April 12, 2001 to April 20, 2003 at the level of (1) the province, (2) the Western Tianshan Forestry Bureau and (3) staff household. Data on secondary resources on the former Yili District and its eight counties and one municipality was also collected. At the provincial level, interviews were conducted with leadership of the Xinjiang 


\begin{tabular}{|c|c|c|c|c|c|}
\hline \multirow[b]{2}{*}{ Ethnic group } & \multicolumn{5}{|c|}{ Year } \\
\hline & 1949 & 1964 & 1982 & 1990 & 1999 \\
\hline Uighur & $38.85 \%$ & $30.28 \%$ & $27.38 \%$ & $27.65 \%$ & $2.68 \%$ \\
\hline Han & $2.22 \%$ & $29.99 \%$ & $35.24 \%$ & $32.25 \%$ & $32.76 \%$ \\
\hline Kazakh & $42.71 \%$ & $25.42 \%$ & $24.25 \%$ & $22.73 \%$ & $22.89 \%$ \\
\hline Hui & $3.91 \%$ & $7.56 \%$ & $9.68 \%$ & $10.54 \%$ & $11.05 \%$ \\
\hline Kirgiz & $2.3 \%$ & $0.84 \%$ & $0.71 \%$ & $0.73 \%$ & $0.75 \%$ \\
\hline Mongolian & $2.61 \%$ & $1.77 \%$ & $1.46 \%$ & $1.38 \%$ & $1.35 \%$ \\
\hline Russian & $2.56 \%$ & $0.08 \%$ & $0.02 \%$ & $0.06 \%$ & $0.06 \%$ \\
\hline Sibo & $2.6 \%$ & $0.28 \%$ & $1.55 \%$ & $1.5 \%$ & $1.54 \%$ \\
\hline Tajik & $0.01 \%$ & $0.00 \%$ & $0.00 \%$ & $0.00 \%$ & $0.00 \%$ \\
\hline Uzbek & $1.31 \%$ & $0.44 \%$ & $0.34 \%$ & $0.33 \%$ & $0.21 \%$ \\
\hline Tartar & $0.64 \%$ & $0.08 \%$ & $0.06 \%$ & $0.05 \%$ & $0.04 \%$ \\
\hline Daur & $0.04 \%$ & $0.04 \%$ & $0.02 \%$ & $0.02 \%$ & $0.02 \%$ \\
\hline Manchurian & $0.11 \%$ & $0.12 \%$ & $0.13 \%$ & $0.16 \%$ & $0.14 \%$ \\
\hline Other & $0.13 \%$ & $1.1 \%$ & $2.16 \%$ & $2.6 \%$ & $2.42 \%$ \\
\hline Total Population & 408294 & 710981 & 1564458 & 1800125 & 2089809 \\
\hline
\end{tabular}

Table 3. Make-up of the labour force in the study area (units: percentage)

\begin{tabular}{|c|c|c|c|c|c|c|c|}
\hline Sector & 1991 & 1993 & 1995 & 1996 & 1997 & 1998 & 1999 \\
\hline Total Workforce (total persons) & 646158 & 683504 & 726697 & 755780 & 836327 & $829 \quad 102$ & $783 \quad 367$ \\
\hline Agriculture, forestry, animal husbandry and fisheries & 59.84 & 60.05 & 67.56 & 60.34 & 70.20 & 10.00 & 69.91 \\
\hline Mining & NA & 3.12 & 1.13 & 1.00 & 0.85 & 0.74 & 0.71 \\
\hline Manufacturing & 13.15 & 9.74 & 8.09 & 8.32 & 6.63 & 5.95 & 5.61 \\
\hline Power, gas, and water & NA & 1.73 & 0.55 & 0.65 & 0.51 & 0.50 & 0.50 \\
\hline Construction & 3.76 & 3.98 & 2.24 & 2.42 & 1.99 & 2.06 & 1.84 \\
\hline Geological survey and water resources management & 0.74 & 0.70 & 0.20 & 0.23 & 0.19 & 0.19 & 0.26 \\
\hline Transport, storage, post and telecommunications & NA & 2.45 & 2.08 & 1.93 & 1.87 & 2.03 & 2.39 \\
\hline Wholesale and retail trade; food and beverage & 8.27 & 5.82 & 6.10 & 6.35 & 6.01 & 6.22 & 6.24 \\
\hline Finance and insurance & 0.53 & 0.53 & 0.54 & 0.57 & 0.42 & 0.44 & 0.53 \\
\hline Real estate & NA & 0.04 & 0.06 & 0.05 & 0.05 & 0.09 & 0.07 \\
\hline Social services & 1.08 & 1.01 & 1.15 & 0.136 & 1.14 & 2.05 & 2.00 \\
\hline Healthcare, sport, and social welfare & 1.65 & 1.26 & 1.21 & 1.81 & 1.47 & 1.53 & 1.30 \\
\hline Education, culture/art, broadcasting /television/film & 5.83 & 4.91 & 4.93 & 4.75 & 4.50 & 4.60 & 4.90 \\
\hline Scientific research and technical services & 0.07 & 0.13 & 0.15 & 0.14 & 0.16 & 0.16 & 0.18 \\
\hline Party and government organization and social groups & 3.70 & 3.49 & 3.08 & 3.10 & 3.03 & 3.16 & 3.33 \\
\hline Other & 1.02 & 1.04 & 0.92 & 0.96 & 0.99 & 0.27 & 0.22 \\
\hline
\end{tabular}

Forestry Bureau. At the level of the Western Tianshan Forestry Bureau, interviews were conducted with the directors of the bureau, as well as department heads. From April 12 to 30,2002 a group discussion, led by the director of the Western Tianshan Forestry Bureau, was held.

In designing a random household survey meant to target at least 100 staff households, the survey team chose to distribute surveyed households among the nine forest centers according to the total number of staff families of each of these. Households were randomly selected at each forest center. Altogether, 112 households were surveyed, distributed as follows: 16 at Zhaosu Forest Center, 15 in Teke'se, Gongliu, Xinyuan, respectively, 11 in Huocheng, and 10 in Chabucha'er, Mengmala, Yining, Nileke, respectively. Household visits were used for completing questionnaires, which covered the objectives, particulars, content, benefits, negative impacts, and suggestions to the NFCP at each of the surveyed households.
As background, $59.8 \%$ of the 112 households surveyed were minority families, roughly reflecting the situation of the forest centers as a whole. Among the minority families, there were 25 Uighur households, 37 Kazakh, 2 Hui, 2 Mongolian and 1 Xibo. There were a total of 525 persons in the 112 families surveyed, of which $52.2 \%$ were female. Among the total number of family members, there were 32 of pre-school age, 157 students of all ages and levels and 13 elderly family members. There were 323 persons that were considered a part of the labour force, of which 43 were out-migrating for work, 131 were unemployed and 149 were in-service staff. Of the inservice staff, educational levels were as follows: $3.36 \%$ illiterate, $26.85 \%$ elementary school educational level, $27.52 \%$ middle school educational level, $26.85 \%$ high school educational level, and $21.48 \%$ post-middle school or post-high technical school or college education level. The average number of household members was 4.69 and the average number per household of in-service staff was 1.33. 
Table 4. Proportion of urban workforce registered as unemployed in the study are

\begin{tabular}{|c|c|c|c|c|}
\hline Year & $\begin{array}{l}\text { Number of } \\
\text { persons } \\
\text { unemployed } \\
\text { in towns }\end{array}$ & $\begin{array}{c}\text { Number of } \\
\text { unemployed } \\
\text { youth }\end{array}$ & $\begin{array}{l}\text { Unemployed } \\
\text { youth as } \\
\text { proportion of } \\
\text { unemployed } \\
\text { persons }\end{array}$ & $\begin{array}{l}\text { Unemploy- } \\
\text { ment rate }\end{array}$ \\
\hline 1985 & 7156 & 6.910 & $96.56 \%$ & NA \\
\hline 1986 & 5806 & 4104 & $70.69 \%$ & NA \\
\hline 1987 & 6421 & 5778 & $89.99 \%$ & NA \\
\hline 1988 & $\begin{array}{ll}10 & 097\end{array}$ & 8745 & $86.61 \%$ & NA \\
\hline 1989 & 7985 & 6556 & $82.10 \%$ & NA \\
\hline 1990 & 8634 & 6587 & $76.29 \%$ & $5.9 \%$ \\
\hline 1991 & 7797 & 5307 & $68.06 \%$ & $4.0 \%$ \\
\hline 1992 & 8357 & 7167 & $85.76 \%$ & $4.0 \%$ \\
\hline 1993 & 8039 & 6932 & $86.23 \%$ & $4.5 \%$ \\
\hline 1994 & 7763 & 6464 & $83.27 \%$ & $4.5 \%$ \\
\hline 1995 & 7998 & 6942 & $86.80 \%$ & $4.2 \%$ \\
\hline 1996 & 7559 & 5134 & $67.92 \%$ & $4.5 \%$ \\
\hline 1997 & 8364 & 5440 & $65.04 \%$ & $4.4 \%$ \\
\hline 1998 & 15196 & 6.100 & $32.29 \%$ & $4.6 \%$ \\
\hline
\end{tabular}

\section{The Impact on Forest, Soil, Water and Biodiversity of the NFCP in the Study Area}

\section{Impact on natural forest}

In terms of current resource base, the study area has 481799 ha of land classified as forestry use land, of which 304066 ha has a canopy density of over 0.2 . The total standing stock of wood is 68.852 million $\mathrm{m}^{3}$, and the average annual natural net increase in standing stock is $1.07 \%$. The net increase in standing stock surpasses $600000 \mathrm{~m}^{3}$ each year. The main natural forest in the mountainous areas of Tianshan is single-species $P$. schrenkiana stands. Survival rates of trees planted as a part of the NFCP in the study area are high — around 95\%. In this regard, then, the program has achieved a high degree of efficiency.

All of the 304066 ha of natural forest in the study area are classified, according to the plan, as "ecological public benefit" forest. Based on the original requirements of the pilot program for natural forest protection and forest establishment, this area was preliminarily divided into two categories. The first, "key ecological public benefit forest," has the sole purposes of soil and water conservation and ecological improvement and is designated for a complete logging ban. It makes up $71.2 \%$ of the total area. The second category, "ordinary ecological public benefit forest," makes up the other $28.8 \%$ of the bureau's forested area and has the purpose of protecting the ecological environment, with limited non-commercial logging being allowed for the purpose of forest tending. After forested areas were divided into these two main groups, a plan for forest establishment and accelerating the recovery of forest resources was designed according to the situation of the forested land and stand composition at various sites. In terms of logging, the plan called for annual timber production of the bureau to be reduced from the pre-ban level of 160000 $\mathrm{m}^{3}$ to $35000 \mathrm{~m}^{3}$ by the year 2000 and the complete elimination of logging instituted by the provincial government in early 2001. The plan also required that afforestation, mountain closure, promotion of natural regeneration, and forest tending all be undertaken according to the annual plans of the state.

\section{Impact on soil and water}

Although the mountainous forested area in study area with a closure of over 0.35 is only about 220000 ha, making up only $3.77 \%$ of the area of the Yili Watershed, as a result of the effects of water and heat factors, the vertical distribution of forest in the various mountain areas corresponds to the distribution of precipitation. Namely, those areas with the highest rainfall are precisely those areas in which forest is located. Thus, beginning from the east of the Yili Watershed with Xinyuan and Nili'ke Counties and moving westward to Chabucha'er County and Huochen County, the mountainous forest stretches $450 \mathrm{~km}$ from east to west and plays an important role in the conservation of water resources and is an important factor in determining the watershed's hydrology. From the above, it can be concluded that preservation of natural forest in the area would have a positive impact on soil and water conservation.

\section{Impact on biodiversity}

The mountainous forest areas in the Yili Watershed are the key breeding grounds of the region's biodiversity. As mentioned, the region is listed as one of the five key terrestrial biodiversity areas with national significance in China (Chen 1993), so the NFCP could potentially play an important role in terms of biodiversity. As discussed, tree planting cannot achieve the same biodiversity benefits as natural forest, so it is of primary importance to protect natural forest, while at the same time pursuing tree planting in areas that have already been deforested.

\section{Problems Encountered Following Implementation of the NFCP}

\section{Technical issues}

Complete logging ban

Perhaps one of the most important technical efficiency issues in the case of NFCP implementation at the study area is whether or not a complete logging ban is necessary. Results from the case study indicate that more flexible policy and scientific guidelines are needed in order to obtain the best technical outcomes of the program. It is important to note that a logging ban cannot replace sustainable forest management.

Several of the representatives of forest farms interviewed discussed the issue of whether a complete ban was necessary and suggested that limited cutting would be a more efficient use of resources. Interviewees from Huocheng Forest Center, for example, commented that a complete ban is a "waste of resources." They suggest that intermediate cutting, carried out in a planned and paced way could be an efficient means of using limited forest resources. Interviewees from Mengmala Forest Center suggested a preferential policy that would allow, over the next ten years, both logging of overmature forest, so as to upgrade the stand, and intermediate disengagement cutting (to foster growth) on a reasonable scale in young and mid-aged stand. They suggest that this would on the one 
hand improve the current forest structure and therefore the quality of the forest, while at the same time generating investment for diversification efforts and training of staff in new technologies, giving both staff and enterprises a period of time to adapt to the needs of the market. Interviewees representing Zhaosu Forest Center also indicated that a full ban is not the best approach. They told the case study team that the center has relatively many overmature trees, so that the physiological function of the standing stock is in decline and its effectiveness in ecological protection has thus dropped. A large number of trees at the center are internally decayed. According to a field survey by the center, this internal decay problem has lowered the commercial timber retrieval rate by $10 \%$ to $20 \%$. Given the situation, the interviewees from Zhaosu believe it would be appropriate to log overmature trees and that it is necessary to carry out upgrading of sparse and deficient forest land.

\section{Grazing}

By way of background, the study area has a forest coverage rate of only $14.1 \%$ and is one of the key grassland areas in Xinjiang for animal husbandry. In the Yili Watershed's west, the mountain areas have an elevation of $1700 \mathrm{~m}$ to $2800 \mathrm{~m}$, while in the east they have elevations of $1500 \mathrm{~m}$ or 1600 to $2800 \mathrm{~m}$. Mountainous forests are interspersed with subalpine meadow. Because of continued growth of the livestock population and the reduction in grassland productivity with increased grazing, pastoralism has gradually been encroaching on forest areas in the summer season. This has caused serious interference in the natural regeneration of forests. Given this situation together with the discontinuation of NFCP afforestation work, not only can natural recovery after the stoppage of logging not be effectively guaranteed, but also it is possible that a reduction in forest area would occur.

Reflecting the seriousness of the issue, many of the forest centers interviewed discussed how grazing lowers the efficiency of natural forest protection work. Interviewees from the Mengmala Forest Center noted that animal husbandry has been developing strongly in their area in recent years, leading to a growth in the number of livestock and overgrazing. Grassland degradation has, in turn, resulted in livestock entering the forests and thus the conflict between forestry and animal husbandry. The Mengmala interviewees note that livestock squeeze into the spaces between trees and move into logged areas that are in the process of regenerating and immature forest, with all of these becoming grazing areas. This affects survival rates, making it hard for forests to naturally regenerate and even make it difficult for afforestation work to achieve good results, thus raising costs. An interviewee from Mengmala concluded that only if "animal husbandry were to yield," could they "recover the forests." Interviewees from Xinyuan Forest Center have similar difficulties. They note that animal husbandry is the number one industry in Xinyuan County and that the local government has set very high goals for the sector in developing the local economy. Xinyuan Forest Center's land spans a width of over $40 \mathrm{~km}$ north to south and $130 \mathrm{~km}$ east to west. With the $30000 \mathrm{mu}(1 \mathrm{ha}=15 \mathrm{mu})$ that it has reforested over the years spread out over this large area, tending and ranging have become more difficult and almost hopeless in the face of the growth of animal husbandry.
Wind-fallen trees

Another technical issue meriting further consideration is that of wind-fallen trees. Currently, with the complete ban, the forest centers are not allowed to collect wind-fallen trees. Indeed, it is true that wind-fallen trees in some cases play an important ecological function and should not be removed. As has been mentioned, the forest of the study area is mainly pure stands of $P$. schrenkiana. In the absence of fire disturbance, regeneration of $P$. schrenkiana depends on disturbance of the forest canopy by forest gaps. Logs making up these gaps are mainly those blown down by wind and, in the absence of interference from animal husbandry, play a key role in the regeneration of P. schrenkiana in the forest district. Currently, however, because the disturbance caused by animal husbandry is quite serious, a portion of the trees blown down by wind have lost their ecological function of promoting regeneration of $P$. schrenkiana. If these logs are not used in a timely fashion, they also lose their economic value. In a typical year, the volume of trees blown down by wind in the study area is 60000 to $70000 \mathrm{~m}^{3}$, and in some years, the figure surpasses $100000 \mathrm{~m}^{3}$.

The interviewees from the Zhaosu Forest Center discussed the issue of wind-fallen trees with the case study team. They indicated that trees blown down by the wind can cause insect or illness disasters and fire hazard and that it is a waste not to use such resources. Acknowledging that trees blown down by the wind can decay gradually and naturally regenerate, the interviewees noted that in their own practical experience, the regenerated trees could not become forest. Rather, as discussed above, animal husbandry interferes with this process. Thus, the interviewees suggest that the forest centers be allowed to collect such trees. Indeed, this issue merits careful consideration. As long as the problem of interference from animal husbandry is not resolved, the option of removing some of the wind-fallen trees should be considered.

\section{Socioeconomic problems associated with complete and immediate logging ban}

In addition to technical issues associated with a complete logging ban, the complete ban and its sudden implementation present substantial social and economic difficulties that may lower the efficiency of the program. The NFCP benefits the people and the nation by reducing logging to improve the environment and is necessary in terms of long-term interests. From the household survey, it can be seen that staff households understand this and support the policy. In the short term, however, a sudden and complete ban appears impracticable from a social and economic point of view. For many different reasons, prior to implementation of the NFCP, the forest industry enterprises in the study area were already, to a certain extent, experiencing economic difficulties. After the launch of the NFCP, both because of the limited nature of subsidies and because shifting to other lines of business and reassignment of staff requires a period of time, more time will be needed before objective results can be obtained from diversification. Suddenly faced with a complete logging ban, the enterprises now have almost no means of making a profit and have no funds for shifting their line of business. It is clearly difficult for the enterprises to adapt to this situation and, without a means of livelihood for staff, there will be extremely serious social consequences, making it impossible 
for implementation of the NFCP to progress smoothly and achieve the targeted results.

The study area has 3651 regular staff considered employees of the state and also 632 staff considered employees of collectives, for a total of 4238 employees. Already, over 600 employees have become unemployed as a result of the ban and indications at the time of research were that the situation would become worse during the second half of 2002. Even for employees who do not lose their positions, NFCP implementation is likely to result in reduced income. Case study results indicate that since the long-standing business structure based on timber production was dismantled, it has been difficult for alternative lines of production to create good economic returns in the short term, so that the profitability of forest enterprises has fallen substantially with implementation. This has in turn directly caused a reduction in staff incomes and a drop in standards of living. Results of the household survey in 2002 indicate that a reduction in household income was indeed a substantial impact for many households of staff in the study area. As indicated in Table 5, more households (49.1\%) reported a drop in income as one of the largest negative impacts of the NFCP on them than any other impact, and $78.2 \%$ indicated that household income dropped after implementation of the program.

Results of the household survey offer special insights into the potential impacts of the program on minorities. Among the 67 minority households surveyed, the average number of family members was 5.41; the average number of working family members was 1.24 , with each working household member (including those successfully out-migrating for work) supporting an average of 4.36 persons. This is higher than the average burden of the surveyed households as a whole by 0.84 persons. It is common for minority households to have more than six persons, but with only one person having a fixed salary. Once this person becomes unemployed or his or her salary is reduced, the basic survival of the household is endangered, and there is no way to guarantee education, medical care, and other basic conditions, causing a high school dropout rate and even a high death rate. Interviewees representing the forest centers also offered insights into the special impacts of the program on minorities. Interviewees from Teke'se Forest Center, for example, explained that minorities make up about half of the center's 580 staff. Most live in forest areas and have relatively many children, with employed family members being few. Because of limited educational opportunities, the children of staff have a low educational level and no special technical skills. They also lack any source of investment to pursue other opportunities, so that the families can depend only on salaries, and if these are not paid on time, they will face difficulties.

With the cessation of logging, it is anticipated that the forest centers in study area will eventually have over $55 \%$ of their staff facing unemployment. Added to this, the ability of the local community to absorb excess labour created by the unemployment of forestry enterprise staff is very low. Thus, the staff will have no security for their livelihoods and will likely become the targets of minority separatist movements, posing a danger to social stability and even national security. Given this situation, the NFCP policies currently in effect in the study area present a certain degree of difficulty in implementation and should receive close attention from policy-
Table 5. Largest negative impacts of the NFCP on staff households

Response Proportion of households

Reduction income

Difficulty sending children to school

Difficulty maintaining livelihood

Unemployment

Lack of guarantee of salary, pension, and health payments

No impacts

$49.1 \%$

$12.5 \%$

$14.3 \%$

$15.2 \%$

$6.3 \%$

$7.1 \%$

Note: Respondents were allowed to choose more than one response.

makers. In particular, given the lack of ability of the local area to contribute to the shifting of lines of business of forestry enterprises and its lack of ability to absorb surplus labour, it is suggested that more state funding is needed to support diversification within the enterprises and creation of alternative livelihoods without.

Results from fieldwork indicate that the NFCP could have serious negative impacts on the social stability of the larger community in which Western Tianshan Forestry Bureau's forest centers are located. Western Tianshan Forestry District is located in the north of Xinjiang, with a part of its forest areas lying close to international borders. Among minority staff, tribal thinking and nepotism are relatively strong. The high unemployment rate, high dropout rate, and high divorce rate caused by the reduction of income of minority staff and the drop in their living standards will not only impact the social stability of the forest district itself, but will also impact the counties and prefecture in which this is located, and even impact the political stability of the whole province. This is an important problem that should attract the attention of government leaders at all levels. Indeed, results of fieldwork indicate that the crime rate in the forest district has already increased.

\section{Sustainability of the Program}

For any project, the participants play a key role in determining whether the project can be sustainable. Results of the staff household survey indicate that under the current policy, the long-term sustainability of the NFCP in the study area is questionable. This is reflected in the following five findings: (1) Most staff know little about the specific content of the policy. (2) The majority (78.2\%) of households interviewed believe that the policy has caused a drop in their income and are feeling very anxious about the situation. (3) The negative impacts on minorities are larger than those on the Han Chinese population. This will cause the NFCP to lose the most basic social basis in minority areas. (4) The employees of enterprises have developed a mentality that is very dependent on the state. This is mainly illustrated in how surveyed households have not thought much about how to raise household income in the immediate future and in that $98.2 \%$ have indicated that the longer the government subsidies, the better. In addition, 95.5\% indicated that they do not think they will have a stable source of income after ten years. (5) The idea of returning to the mountains for logging has not been completely abandoned. Of surveyed households, 
$6.4 \%$ indicated that once subsidies stopped they would return to the mountains for logging.

In order to strengthen the long-term sustainability of the NFCP in the study area, the factors threatening sustainability of the program must be addressed. First, public awareness work must be increased, so that the bulk of forestry workers understand the specifics of the policy and that those involved become fully supportive of the policy. Second, a more flexible policy should be adopted to resolve technical, social and economic problems, so that livelihoods are ensured for forest workers and so that a simple ban on logging is not used in place of what is really needed to ensure natural forest protection. Third, the NFCP should be made suitable to the local situation, rather than instituting a single policy for all. More state funding is needed to support diversification within the enterprises and creation of alternative livelihoods without. The special situations of remote, undeveloped minority areas must be considered.

\section{Acknowledgements}

The authors are grateful to the Natural Science Foundation of China (NSFC; Project No: 30470330, 30360087) for the financial support of the work.

\section{References}

Chen, L.Z. 1993. In China's Biodiversity. pp.195-196. China's Scientific Publishing House, Beijing. (in Chinese).

Li, W. 1993. In China's Biodiversity. p. 168. China's Scientific Publishing House, Beijing. (in Chinese).

Ministry of Forestry. 1997. China's Forestry Yearbook. China's Forestry Publishing House, Beijing

Shaw, N. 1914. Chinese Forest Trees and Timber Supply. T. Fisher Unwin, London.

Qu, G. 1999. Environmental Protection Knowledge. China's Red Flag Publishing House, Beijing. 354 p. (in Chinese).

Zhao, G.. and G.F. Shao. 2002. Logging restrictions in China: A turning point for forest sustainability. Journal of Forestry 100(4): 34-37. Zhang, P., G. Shao, G. Zhao, D.C. Lemaster, G.R. Parker, J.B. Dunning and Q. Li. 2000. China's forest policy for the 21st century. Science 288 (5474): 2135-2136.

Zhang, P., X. Zhou and F. Wang. 1999. Introduction to Natural Forest Conservation Program. China's Forestry Publishing House, Beijing. (in Chinese). 